\title{
Peningkatan Produktivitas dan Penjualan pada UMKM Pakaian Muslimah Ummu Syuraih di Kecamatan Medan Marelan
}

\author{
Lily Karlina Nasution ${ }^{1 *}$, Mayang Murni², Ika Sari Dewi ${ }^{3}$ \\ ${ }^{1,2}$ Program Studi Akuntansi, Politeknik LP3I Medan \\ ${ }^{3}$ Program Studi Administrasi Bisnis, Politeknik LP3I Medan \\ *lilykarlinanasution@gmail.com
}

\begin{abstract}
ABSTRAK
Persaingan yang ketat menuntut UMKM untuk aktif dalam melakukan inovasi baik dari segi produk, pemasaran dan pengembangan usaha. UMKM Ummu Syuraih memproduksi pakaian muslimah meliputi gamis, khimar dan niqab. UMKM Ummu Syuraih juga mengalami beberapa kendala dalam menjalankan usahanya diantaranya tata kelola manajemen keuangan yang masih manual, keterbatasan kemampuan SDM dan mesin produksi, pemasaran produk yang masih menggunakan cara word of mouth marketing, dan tampilan kemasan produk yang kurang menarik. Tujuan dari kegiatan pengabdian masyarakat ini untuk 1) UMKM Ummu Syuraih dapat mengelola manajemen keuangan usahanya secara professional, 2) meningkatkan kapasitas produknya melalui peningkatkan keahlian dan keterampilan sumber daya manusianya, 3) memperluas jaringan pemasaran produk melalui strategi bauran pemasaran yang tepat, 4) meningkatkan tampilan kemasan pada produk yang dihasilkan. Kegiatan dalam pengabdian kepada masyarakat ini meliputi pelatihan (kemampuan menjahit, manajemen pemasaran, manajemen keuangan dengan menggunakan aplikasi penjualan dan website), pendampingan (penggunaan aplikasi penjualan dan website), dan hibah alat. Berdasarkan pelaksanaan dan evaluasi hasil kegiatan dapat disimpulkan UMKM Ummu Syuraih dapat menjalankan usahanya secara professional serta terdapat peningkatan kapasitas produksi dan penjualan dikarenakan bertambahnya permintaan dari pelanggan.
\end{abstract}

Kata Kunci: UMKM, Produktivitas, Pemasaran, Penjualan.

\begin{abstract}
Intense competition requires MSMEs to be active in making innovations in terms of products, marketing and business development. UmmuSyuraih MSMEs produces Muslim clothing including robe, khimar and niqab. UmmuSyuraih MSMEs also experienced several difficulties in making her business, including manual financial management, limited human resource capabilities and production machines, using word of mouth marketing, and less attractive product packaging. The purposes of this community service activity are 1) UmmuSyuraih MSMEs is able to manage the financial management of her business professionally, 2) increase the capacity of its products by increasing the skills of its human resources, 3) expanding the product marketing network through the proper marketing mix strategy, 4) renewing the packaging on their product. Activities in this community service include training (sewing ability, marketing management, financial management by using sales applications and websites), mentoring (the usage of sales applications and websites), and tool grants. Based on the implementation and evaluation of the activities, it can be concluded that UmmuSyuraih MSMEs is able to manage her business professionally and there is an increase in production and sales capacity due to increased demand from customers.
\end{abstract}

Keywords : MSMEs, Productivity, Marketing, Sales

\section{PENDAHULUAN}

Usaha Mikro Kecil dan Menengah (UMKM) merupakan tulang punggung perekonomian Indonesia. Di saat sektor usaha lainnya tergerus krisis ekonomi pada tahun 1998, hanya UMKM yang mampu bertahan bahkan UMKM mampu menyerap 85 juta hingga 107 juta tenaga kerja sampai dengan tahun 2012. Berdasarkan data badan kajian nasional
Bank Indonesia jumlah pengusaha di Indonesia pada saat itu sebanyak 56.539.560 unit dengan klasifikasi UMKM sebanyak $99.99 \%$ atau 56.534 .592 unit dan sisanya sekitar $0,01 \%$ atau 4.968 unit adalah usaha besar. Data tersebut membuktikan bahwa UMKM mampu bertahan walau ditengah krisis sekalipun. 
Meskipun jumlah pelaku UMKM cukup banyak dan memberikan kontribusi yang besar bagi perekonomian nasional, tetapi masih ada saja UMKM yang mengalami kesulitan dalam mengembangkan usahanya. Secara umum, ada beberapa persoalan yang dihadapi oleh pelaku UMKM. Persoalan tersebut meliputi akses keuangan/permodalan, pemasaran, manajemen keuangan dan usaha, aspek hukum/legal dan aspek perpajakan.

Banyak pelaku UMKM yang mengelola usahanya tanpa memiliki pengetahuan dasar maupun keterampilan mengenai manajemen usaha dan manajemen keuangan yang baik. Kebanyakan dari usaha tersebut dijalankan hanya dengan mengandalkan insting dan pengalaman pribadi atau referensi dari teman, saudara atau pun keluarga yang telah lebih dahulu terjun di dunia usaha (UMKM) saja. Aspek-aspek manajemen usaha yang meliputi perencanaan usaha, pengorganisasian, implementasi, dan pengendalian usaha jarang menjadi perhatian para pelaku usaha. Demikian pula dengan aspekaspek manajemen keuangan yang sebenarnya sangat penting dalam menghitung keuntungan usaha juga luput dari perhatian para pelaku UMKM. Padahal hal tersebut sangat penting dalam membangun dan mengembangkan usaha. Perhitungan laba sering dilakukan dengan sederhana tanpa melakukan perincian biaya secara menyeluruh. Misalnya usaha yang menggunakan bahan baku/bahan mentah dari lahan sendiri dan melibatkan anggota keluarga sendiri biasanya tidak dimasukkan ke dalam komponen biaya bahan baku dan biaya tenaga kerja dalam penghitungan biaya. Sehingga pengelolaan keuangan yang dilakukan para pelaku usaha masih belum tepat dan optimal (Subanar, 2011).

Perkembangan jumlah UMKM terjadi di berbagai sektor ekonomi termasuk sektor perdagangan, hotel dan restauran. Sektor perdagangan, hotel dan restoran sendiri merupakan sektor kedua terbesar yang mengalami peningkatan jumlah
UMKM yaitu sebesar $28,83 \%$. Sektor perdagangan meliputi kegiatan penjualan kembali (tanpa perubahan teknis) barang baru maupun bekas. Sektor inilah yang paling banyak diminati oleh pelaku UMKM karena dianggap sebagai sektor yang paling cepat menghasilkan keuntungan dan resiko yang kecil (Sujatmiko, 2018).

Salah satu sektor perdagangan yang paling banyak diminati para pelaku usaha adalah usaha industri pakaian muslimah. Pakaian muslimah merupakan hal yang wajib dikenakan oleh setiap muslimah sesuai dengan perintah Al-quran dan hadist. Dengan jumlah penduduk muslim terbesar di dunia menjadikan Indonesia sebagai pangsa pasar yang potensial bagi pelaku usaha di industri pakaian muslimah. Dalam perkembangannya, industri pakaian muslimah tidak hanya didominasi oleh perusahaan besar saja, namun usaha kecil dan menengah pun ikut memberikan andil dalam perkembangan perekonomian di industri pakaian muslimah. Oleh karena itu diperlukan adanya pengembangan dan pembinaan yang berkesinambungan guna meningkatkan kemajuan pada UMKM pakaian muslimah agar mampu mandiri dan menjadi usaha yang tangguh.

Perkembangan pakaian muslimah dari tahun ke tahun mengalami kemajuan yang sangat signifikan hal ini dibuktikan dengan makin banyaknya bermunculan UMKM yang memproduksi segala jenis pakaian muslimah, mulai dari pakaian gamis, jilbab, mukena sampai dengan legging dan handsock. Pakaian muslimah tidak lagi memiliki model dan jenis yang itu-itu saja tetapi sekarang pakaian muslimah lebih beragam jenisnya dan lebih fashionable tetapi tidak melupakan syarat syariatnya yaitu longgar dan tidak membentuk badan. Para desainer dan pemerhati mode telah banyak menciptakan berbagai macam pakaian muslimah sesuai dengan kebutuhan para wanita muslimah modern yang juga memiliki segudang aktifitas. Hal ini menjadikan bisnis pakaian muslimah 
lebih diminati untuk dijadikan bisnis sampingan maupun main Bussiness.

Ada beberapa karakteristik yang terdapat pada usaha kecil pada umumnya yaitu: 1) usaha informal yang memiliki aset modal, omzet yang amat kecil dan kapasitas produksi yang rendah, 2) lemah dalam manajemen, teknologi, dan informasi pasar, 3) dikelola dalam manajemen keluarga sehingga lemah dalam pengendalian, 4) tidak menguasai saluran distribusi dan lemah dalam pemasaran, 5) tidak memiliki legalitas usaha, 6) memiliki kelemahan dalam manajemen keuangan sehingga lembaga keuangan formal mengalami kesulitan dalam mengukur kemampuan usahanya (Partomo dkk, 2011).

Mitra UMKM Ummu Syuraih ini berdiri pada tahun 2016 dengan memproduksi pakaian muslimah yang simple dan terjangkau tetapi tetap memiliki kualitas yang baik. Selain pakaian muslimah mitra juga memproduksi khimar dan niqab. Model dan jenis kain dipilih langsung oleh mitra demi menjaga kualitas dari pakaian muslimah yang diproduksinya. Dalam satu bulan mitra hanya dapat memproduksi 20-50 pakaian muslimah dengan model yang simple dan praktis. Hal ini dikarenakan kurangnya alat produksi, tenaga kerja dan terbatasnya kemampuan sumber daya manusia untuk membuat model pakaian muslimah yang lebih bervariasi. Mitra melakukan penjualan produknya secara langsung dengan membuka toko dan membuka stan-stan di berbagai kesempatan.

Kegiatan mitra bergerak di ekonomi kreatif yang terus berkembang seiring dengan meningkatnya kesadaran akan berpakaian muslimah. Kegiatan ekonomi kreatif yang dilakukan oleh mitra sejalan dengan tujuan Politeknik LP3I Medan yakni mencetak usahawan muda yang kreatif dan inovatif. Selain sejalan dengan tujuan Politeknik LP3I Medan, bidang yang akan dikembangkan dalam proses pengabdian ini sesuai dengan fokus keilmuan yang ada di Politeknik LP3I
Medan yakni akuntansi, pemasaran, produksi, dan teknologi komputer.

Persiapan kegiatan pengabdian kepada masyarakat ini diawali dengan diskusi dan kordinasi yang dilakukan antara tim pelaksana PKM dengan mitra UMKM. Diskusi dan kordinasi dilakukan untuk mengetahui kegiatan apa saja yang akan dilakukan dan capaian yang ingin dicapai oleh mitra UMKM serta menentukan prioritas kegiatan yang akan dilaksanakan. Dalam kegiatan ini ditentukan jadwal pelatihan dan pendampingan yang akan dilakukan terhadap mitra.

Melalui diskusi yang dilakukan dengan mitra didapatkan beberapa permasalahan dalam meningkatkan penjualan di antaranya adalah 1) Tata kelola manajemen keuangan yang masih manual; 2) keterbatasan mesin produksi; 3) belum menggunakan strategi bauran pemasaran dalam memasarkan produknya; dan 4) tampilan kemasan yang kurang menarik.

Bauran pemasaran adalah perangkat alat pemasaran taktis yang dapat dikendalikan, produk, harga, distribusi, dan promosi yang dipadukan oleh perusahaan untuk menghasilkan respons yang diinginkan dalam pasar sasaran (Kotler \& Amstrong, 2011). Dengan mengetahui bauran pemasaran pengusaha akan lebih mudah meningkatkan produksi dan penjualan produk usahanya. Selain itu tampilan kemasan (packaging) tidak kalah penting dalam sebuah usaha. Banyak pelaku UMKM yang kurang memberi perhatian terhadap kemasan produk. Ada yang berpikir bahwa yang terpenting dalam pemasaran produk adalah kualitas produknya padahal kemasan adalah salah satu hal yang dapat mempengaruhi penjualan. Kemasan yang baik dapat membangun ekuitas merek dan mendorong penjualan (Kotler \& Keller, 2011).

Adapun tujuan dari dilaksanakannya kegiatan pengabdian kepada masyarakat ini adalah : 1) UMKM Ummu Syuraih dapat mengelola manajemen keuangan usahanya secara professional; 
meningkatkan kapasitas produknya melalui peningkatkan keahlian dan keterampilan sumber daya manusianya; 3) dapat memperluas pasar bagi produk yang dihasilkannya melalui strategi bauran pemasaran yang tepat; 4) meningkatkan tampilan kemasan produk yang dihasilkan.

\section{METODE}

Bahan yang disiapkan sebelum pelaksanaan kegiatan pengabdian kepada masyarakat ini meliputi materi pelatihan dan pendampingan yang akan diberikan kepada UMKM Ummu Syuraih, sosialisasi kegiatan kepada mitra, bahan/alat yang diberikan untuk meningkatkan produksi diantaranya adalah, mesin jahit, kain, gawang baju untuk pameran, label baju, plastik kemasan dan goodiebag, dan dokumentasi kegiatan.

\section{Metode Pelaksanaan Kegiatan}

Metode kegiatan pengabdian kepada masyarakat dilaksanakan dalam beberapa tahapan yaitu:

1. Pelatihan Kemampuan Menjahit

Pelatihan kemampuan menjahit ini bertujuan untuk meningkatkan kemampuan dan keterampilan mitra dalam membuat dan menghasilkan produk (gamis, khimar, niqab) yang sesuai dengan permintaan pasar. Pelatihan secara privat dilakukan 6 kali seminggu dengan durasi waktu 2 jam per pertemuan selama 3 bulan di PT. Singer wilayah Sumatera yang beralamat di jalan SM. Raja No 310 Medan

2. Pelatihan manajemen keuangan dan laporan keuangan sederhana

Pelatihan manajemen keuangan bertujuan untuk meningkatkan pemahaman dan pengetahuan dalam pembuatan laporan keuangan sederhana melalui aplikasi keuangan sehingga mitra UMKM dapat membuat manajemen keuangan yang lebih terperinci yang dapat membantu mitra dalam menghitung keuntungan dan mengelola keuangan usahanya secara baik dan optimal. Pelatihan penggunaan aplikasi manajemen keuangan oleh Kurnia Arja Kesuma, S. Kom

3. Pelatihan manjemen pemasaran

Pelatihan manajemen pemasaran bertujuan untuk meningkatkan pemahaman dan pengetahuan mitra dalam bidang pemasaran khususnya strategi bauran pemasaran. Materi pelatihan mencakup konsep dasar pemasaran, proses perencanaan pemasaran, analisis peluang pasar, dan perencanaan strategi pemasaran (Tjiptono, 2011). Pelatihan ini dilaksanakan secara langsung selama 1x120 meni oleh Iwan Kesuma Sihombing, S.Sos, M.Si.

4. Pelatihan penggunaan website mitra UMKM

Pelatihan ini bertujuan untuk meningkatkan pemahaman dan pengetahuan dalam penggunaan penggunaan website UMKM Ummu Syuraih sebagai sarana pemasaran yang optimal. Melalui website tersebut mitra dapat memasarkan produknya tidak hanya terbatas untuk wilayah Medan saja tetapi juga dapat menjangkau seluruh wilayah Indonesia bahkan di seluruh dunia. Hal ini membuka kesempatan yang lebih luas bagi UMKM Ummu Syuraih untuk dapat memperkenalkan produk-produknya yang tentu saja dapat meningkatkan keuntungan usahanya. Pelatihan penggunaan website oleh Kurnia Arja Kesuma, S. Kom Pelatihan dilaksanakan secara tatap muka dan praktik penggunaan website selama 1x120 menit.

5. Pemberian stimulan bahan dan alat Stimulan yang diberikan berupa bahan/alat yang memadai untuk menunjang proses produksi dan penjualan seperti, mesin jahit, kain, gawang baju untuk pameran, label baju, plastik kemasan dan goodiebag sehingga kapasitas produksi dan penjualan dapat ditingkatkan, serta 
permintaan konsumen dapat dipenuhi.

6. Pendampingan penyusunan laporan keuangan, penggunaan aplikasi manajemen keuangan dan website mitra UMKM

Kegiatan pendampingan penyusunan laporan keuangan, penggunaan aplikasi manajemen keuangan dan website dilakukan untuk membantu mitra mengaplikasikan semua pelatihan yang sudah didapatkannya secara langsung.

\section{Partisipasi Mitra Dalam Pelaksanaan Kegiatan Pengabdian}

Partisipasi mitra dalam pelaksanaan program merupakan unsur yang paling utama dalam kegiatan pengabdian kepada masyarakat. Sebelum pelaksanaan kegiatan pengabdian, mitra diberikan informasi mengenai tujuan, manfaat, dan waktu pelaksanaan kegiatan. Bentuk partisipasi mitra diantaranya adalah: 1) memberikan informasi mengenai kegiatan usaha yang sedang dijalankan dengan segala kendala yang dihadapinya; kegiatan pengabdian ini dapat memberikan manfaat sesuai dengan apa yang diinginkan mitra; 3) menyediakan waktu dan tenaga untuk terlaksananya kegiatan pengabdian ini hingga selesai.

\section{Evaluasi Pelaksanaan dan Keberlanjutan Kegiatan Pengabdian}

Evaluasi ini bertujuan untuk mengetahui tingkat keberhasilan kegiatan pengabdian kepada masyarakat ini terhadap pencapaian mitra. Indikatornya adalah terjadinya peningkatan usaha yang dijalankan oleh UMKM Ummu Syuraih seperti halnya : peningkatan produksi, peningkatan penjualan /omzet, perluasan pangsa pasar, dan kemajuan usaha dapat diukur melalui pencatatan laporan keuangannya. Sedangkan keberlanjutan kegiatan pengabdian diindikasikan dengan keberlangsungan UMKM Ummu Syuraih dan pencapaian kemajuan usahanya. Peningkatan yang telah dicapai dalam hal peningkatan produksi dan penjualan setelah pelaksanaan program dapat dilihat melalui tabel di bawah ini:

2) memberikan saran/masukan sehingga

Tabel 1. Capaian Peningkatan

\begin{tabular}{lrrr}
\hline & $\begin{array}{c}\text { Sebelum dikenai } \\
\text { program }\end{array}$ & Setelah dikenai program & Kenaikan \\
\hline Penjualan & 104 & 179 & $27 \%$ \\
\hline Omset Rata-Rata & $13,000,000$ & $22,375,000$ & $27 \%$ \\
\hline Produksi & 110 & 186 & $26 \%$ \\
\hline Laba & $3,640,000$ & $6,265,000$ & $27 \%$ \\
\hline
\end{tabular}

HASIL DAN PEMBAHASAN

Pelatihan kemampuan menjahit diberikan untuk meningkatkan kemampuan dan keterampilan mitra dalam memproduksi barang dengan jenis yang berbeda sesuai dengan pemintaan pasar. Pelatihan ini dapat meningkatkan keterampilan mitra dalam membuat pakaian muslimah dengan baik dan lebih bervariasi. Pelatihan manajemen keuangan diberikan untuk meningkatkan pemahaman dan pengetahuan mitra dalam mengelola manajemen keuangan yang tepat dan efektif. Materi yang diberikan berupa teori tentang manajemen keuangan (pengelolaan keuangan dan akuntansi keuangan). Selain itu aplikasi manajemen keuangan untuk memudahkan mitra dalam mencatat laporan keuangannya secara tepat dan terperinci.

Pelatihan manajemen pemasaran diberikan untuk meningkatkan pemahaman dan pengetahuan mitra dalam bidang pemasaran khususnya strategi bauran pemasaran. Materi dalam pelatihan ini ditekankan pada strategi promosi yang tepat bagi produk yang dipasarkan, sehingga meningkatkan omzet penjualan. Selain itu, untuk 
perluasan jangkauan pemasaran atau promosi pemasaran produk juga dilakukan dengan menggunakan website sehingga dapat menjangkau lebih banyak konsumen.

Pemberian stimulan bahan/alat bertujuan untuk meningkatkan kegiatan produksi sehingga kapasitas produksi dapat ditingkatkan untuk memenuhi permintaan konsumen. Adapun bahan/alat yang diberikan untuk meningkatkan produksi diantaranya adalah, mesin jahit, kain, gawang baju untuk pameran, label baju, plastik kemasan dan goodie bag.

Dari hasil kegiatan yang dilaksanakan pada mitra diketahui bahwa penjualan produk mitra sebelum dikenai program berjumlah 104 produk dan setelah dikenai program mitra dapat meningkatkan penjualan menjadi 179 produk atau meningkat sebesar 27\%. Kemudian kapasitas produksi mitra juga mengalami peningkatan sebesar 26\% yaitu dari 110 produk menjadi 186 produk. Seiring peningkatan penjualan dan kapasitas produksi maka omset ratarata yang dihasilkan mitra juga ikut meningkat sebesar $27 \%$ dari $13,000,000$ menjadi 22,375,000. Selain itu laba yang dihasilkan oleh mitra juga mengalami peningkatan sebesar $27 \%$ dari 3,640,000 menjadi 6,265,000. Hal ini membuktikan bahwa program kemitraan masyarakat ini sangat membantu mitra dalam mengelola usahanya menjadi lebih baik lagi.

Pendampingan dilaksanakan agar mitra memiliki kesempatan yang lebih banyak untuk mempelajari dan mempraktikkan materi pelatihan yang sudah diberikan. Selama pendampingan juga diberikan contoh-contoh penerapannya dalam usaha yang sedang dijalankan. Selain itu mitra dapat berdiskusi langsung dengan tim pelaksana pengabdian jika menemui kesulitan dalam penggunaannya. Setelah kegiatan pendampingan selesai maka kegiatan selanjutnya adalah monitoring dan evaluasi untuk melihat besarnya capaian yang dicapai.
Pelatihan dan pendampingan yang diberikan kepada UMKM Ummu Syuraih telah memberikan dampak positif bagi pengembangan usahanya, antara lain:

1. Meningkatnya kemampuan dan keterampilan mitra dalam memproduksi pakaian muslimah, indikasinya adalah adanya produk yang dihasilkan dengan jenis dan model yang bervariasi sehingga dapat melayani permintaan konsumen.

2. Meningkatnya pemahaman dan pengetahuan mitra mengenai tata kelola manajemen keuangan yang baik melalui penggunaan aplikasi keuangan, indikasinya adalah mitra lebih mudah dalam mengelola keuangan usahanya.

3. Mitra dapat memperluas jaringan pemasarannya sampai ke seluruh dunia melalui penggunaan website. Hal ini diindikasikan dengan peningkatan penjualan dan permintaan konsumen yang berasal dari luar daerah.

4. Meningkatnya pemahaman dan pengetahuan dalam menjalankan dan mengembangkan usaha, indikasinya adalah dengan peningkatan kapasitas produksi, kinerja yang efisien, tata kelola manajemen keuangan yang tepat dan teratur serta jaringan pemasaran yang lebih luas.

\section{SIMPULAN}

Berdasarkan kegiatan pengabdian kepada masyarakat yang telah dilaksanakan dapat disimpulkan sebagai berikut :

1. Kegiatan pengabdian kepada masyarakat ini mendapatkan respon yang sangat baik dari mitra, hal ini dibuktikan dengan partisipasi aktif mitra dalam mengikuti pelatihan dan pendampingan yang diberikan.

2. Mitra mendapatkan manfaat dari kegiatan pengabdian kepada masyarakat ini dalam bidang tata kelola manajemen keuangan, bidang manajemen pemasaran, dan 
peningkatan kapasitas produksi dari usaha yang dijalankan.

3. Adanya peningkatan produksi dan penjualan seiring dengan bertambahnya permintaan konsumen sebagai dampak dari lebih luasnya jaringan pemasaran.

\section{DAFTAR PUSTAKA}

Kotler, Philip and Armstrong, Gary. (2011) Dasar-Dasar Pemasaran. Jilid 1. Jakarta : Prenhallindo.

Kotler and Keller. (2012). Manajemen Pemasaran, Edisi 12. Jakarta : Erlangga.

Partomo, Titik S and Soejoedono, A R. (2011). Ekonomi Skala Kecil/Menengah dan Koperasi. Jakarta : Ghalia Indonesia

Subanar, Harimurti. (2011). Management Usaha Kecil. Yogyakarta : BPFE.

Tjiptono, Fandy. (2011). Strategi Pemasaran. Yogyakarta : Andi Offset.

http://krjogja.com/read/208235/briperluas-umkm-di-sektorperdagangan (diunduh 18 Agustus 2018)

https://www.bi.go.id/id/umkm/penelitian/ nasional/kajian/Pages/ProfilBisnis UMKM.aspx. (diunduh 18 Agustus 2018) 